\title{
Preface
}

Under the influence of its leading factfinder, the highly Germanic, highly authoritative, intransigent defender of reason of state Francisco Adolfo de Varnhagen, Brazilian historiography has, as Capistrano de Abreu said, been molded with an iron hand. ${ }^{*}$ Everything that failed to come up to officially approved standards, every failure to conform, every evidence of radicalism was rejected or reproved. For the professionals and for the elite, Varnhagen's História Geral do Brasil" ("General History of Brazil") represents a remarkable effort, an extraordinary service from the viewpoint of research, of the accumulation of data, and of the establishment of dates, names, and facts. It is a milestone in Brazilian historical writing, but it attributes only marginal importance to the common people, who, however, were the true forgers of the country's material development and of Brazilian national character. Varnhagen's view served the purposes of the dominant elite and became incorporated into its ideology. His view set a seal of approval on Portuguese colonial policy in Brazil; it reinforced the thesis favoring the survival of obsolete, archaic institutions; it rejected every radical concept or idea of reform that appeared in the colonial period and that had a role in the struggle for independence or in the various rebellions that shook the country.

Ever since, this conservative line of thought has predominated in the interpretation of Brazilian history, despite the attempts of a few-such as Capistrano de Abreu, João Ribeiro, and Euclides da Cunha-to provide a new orientation in the years from 1900 to 1907. As their work was not of a general nature, being of the essay type or dealing with periods or episodes, it lacked the bulk required, if not to overcome, at least to counterbalance the conservative influence of Varnhagen. These three writers began what Francisco de Assis Barbosa has called "a Mod-

\footnotetext{
* Francisco Adolfo de Varnhagen (1816-1878) was the first Brazilian national historian of importance. João Capistrano de Abreu (1853-1927) was doubtless the most important of Brazil's historians. He achieved a brilliant synthesis in his writings, most notable in his Caminhos Antigos e Povoamento do Brasil, Capítulos de História Colonial, 1500-1800, and Ensaios e Estudos.

1 Francisco Adolfo de Varnhagen, História Geral do Brasil.
} 
ernist revolution in history," owing either to their choice of topics or to their manner of interpretation. Since, according to the conservative theory, the populace has no part in the historical process, the privileges and benefits which the state can confer belong by right to the real or titular holders of power. This myth has contributed still further to rendering the elite sterile and lacking in creativity; it has brought about a leadership vacuum which has greatly harmed the country and would have done so to a further extent were it not for the sterling qualities of the common people.

In a country which has been living in a state of volatility, the problem of overcoming the crises of growth has been aggravated by this vacuum and, simultaneously, by the presence of false leaders of the agitator type, restless and dominated by feelings of shame and guilt. It is those feelings which are responsible for the long-winded outbursts in which they defend their own honor and attack that of others. They forget that the only honor important in history is national or public honor. In conformity with Varnhagen's view of reason of state, however, no history has taken the common people into account or expressed a belief in the value of their services. Some historians took fright at what the consequences might be if their studies of the past were carried forward to more recent periods. Some drew back and, turning from their initial attempts at renovation, subjected themselves completely to the dominant view, as established by Varnhagen, of the benefits of the quasifeudal Portuguese colonial structure, praising it as he had done. Still others attributed the evils of Brazil to the populace, which they transformed into the villain of the country's history: The nation's capital defects derived from the covetousness of the Portuguese, the sensuality of the Negro, and the indolence of the Indian. Nothing could be done about it: Brazil was all wrong, for that reason and for that reason alone. A dominant minority had created all that was good and civilized in the country; consequently, it was the sole personage worthy of emphasis in the pages of history. Since the populace was to be deplored and since history had been made by the minority, just as government was conceived as government by the elite, so also history was conceived as the history of the elite.

There has always been a profound disdain in Brazil for national reality, especially on the part of the dominating minority, whose successive generations have held power ever since the winning of independence. Tradition is the sacred name invoked in the battle against innovations and changes proposed by rationalists and radicals. Brazil has always been 
the prey of an antipolitical sentiment which, viewing political ideals and principles as abstractions and distortions, has concealed national reality or conjured it out of sight. National reality is a sum of regional realities, of contrasts and similarities. Only rarely has it been captured. It was a Frenchman, Jacques Lambert," who had a vision of "the two Brazils." There are many realities. There is an official reality, better expressed by the national budget than in the constitution or in presidential messages; there is a practical-theoretical reality, which many writers in the fields of fiction and of the social and historical sciences seize upon, to the displeasure or suspicion of the political opportunist; and there is a marginal reality, which is not foreign to the course of history, but which is ignored by official history and policy. In a country in which the sphere of the possible greatly exceeds that of the real, as José Bonifácio said, people rub their eyes and do not believe what they see. Reality or realism is a myth to the minority. The problem consists in knowing whether the confusion of the real with the possible or of myth with reality is the result of insuperable difficulties or of a generalization of the ineptness that is characteristic of the elite.

Reality has been captured in fragments, in segments of life, by some writers, through intuition or study; it has been discerned in certain phases by creative leaders who were exiled or expelled from participation in the nation's historical development, or who gave up, or committed suicide, or compromised themselves by acts of conformity or conciliation; and, finally, it has been perceived by the common people, whose role, though unappreciated, represents the great success story in Brazilian history, just as the role played by the dominant minority is a disappointment.

The time for change has come, however, and the giant will arise and move forward under the direction of creative minorities inspired in the interest of the common people and the nation. In view of its size $\dagger$ and great expectations, Brazil does not wish to run the risk of a major explosion. Excitement over growth, with an increased hope for more educated people, better housing, larger salaries, and better standards of living, is no mere hullabaloo raised for the benefit of political orators. It expresses concern for more civilized ways of life and for an end to

* The fascinating study of Brazil made by Jacques Lambert is Le Brésil: Structure sociale et Institutions politiques.

$\dagger$ Brazil in 1967 boasts a population of over eighty million, a fraction of what this nation, the fifth largest in the world, with $3,286,169$ square miles, could support. About two thirds of the population is concentrated in the one third of the territory fronting on the Atlantic Ocean. 
the archaic feudal relics of colonial times which have remained imbedded in national existence.

There is, in fact, a general desire for structural change, for new forms of administration that satisfy national interests and popular aspirations. I realize that the expression "national interest" is used in a vague, abstract sense. Nevertheless, it has an objective, practical sense, as the constitution itself recognizes. National interest is what serves the interests of the common people and the federal union, in whose name the nation was constituted.

Consequently, a new view must be taken of history, a view that recognizes the virtues and the achievements of the common people and sees that the populace is assigned its due place in the body politic. Fortunately, this has been done recently in a few pioneering works in the social sciences and in fiction, the last-mentioned being the farthest in the van. The heart and the hands of the common people have made Brazil what it is and not what the elite would like it to be. For this reason it is necessary to eliminate the pseudo happening or pseudo fact-a piece of information which is true, but which is silly, insignificant, and empty, and which conveys a false view of historical development. Hence the false legends and the depressive effects created by certain works of elite tendencies which seek merely to uphold outworn privileges and ensure the persistence of traditional patterns, or to explain away failures of leadership and justify the condemnations pronounced by certain groups, the basis for which is nothing but intolerance.

Brazilian history has neglected the common people and concentrated on the role played by leaders, praising them without passing judgment on their responsibilities. The populace has always been presented as a fearsome specter-fatalistic, subservient, gloomy, vegetating in indifference to pseudo happenings. Leaders have always been made to appear capable, gallant, efficient, brilliant, roseate, hindered from advancing by hoi polloi. But past history, like the future, represents a hope if it uncovers errors, reveals what is sound, and clears the way for the development of positive values by removing the inhibitions occasioned by a falsely roseate presentation of the past.

It would be neither desirable nor right to deny the greatness of figures who struggled in the past to create the future. In the case of a historiography dominated by attention to personalities and biography, however, it is good not to forget that the ways of elder generations-what is termed tradition, as opposed to truth-can result in inertia and have regressive effects. 
This book was born of a desire to see contemporary events in their historical perspective. It is suggestive rather than exhaustive; it seeks to arrive at understanding rather than judgment. Briefly, I believe that it presents a few new viewpoints - which may be the object of controversy -without any attempt at sweeping the past under the carpet. It makes no pretense at building up anyone's hopes, but its optimistic tone (indicative of a belief in salvation rather than in the damnation in which certain indignant political leaders place their trust) represents a position taken in opposition to the antipopular theses of certain currents of Brazilian historical and biographical writing. The Brazilian people suffer from economic and cultural deficiencies, as their history plainly indicates, but they have shown themselves capable of singular deeds and undertakings.

The Brazilians: Their Character and Aspirations was written under the incitement of a moment of great creative hopes in the nation's life and of the enthusiasm generated by recent decades of development. Despite the attendant inflation, the creation of Brasilia brought a faith in the future such as had rarely been known in Brazil. But the truth is that the course of Brazilian history does not follow a straight line of development but a cyclical path, with phases of advance and phases of retreat, in view of the formidable resistance offered by certain economic groups and reactionary leaders. Periods of progress are followed by times of stagnation, depending on leaders, economic conditions, and international situations.

The dispute dates from the revolution of $1930,{ }^{*}$ regarded by some as a creative movement, characterized by industrialization, nationalism, and development, and considered by others as a chaotic eruption of the forces of destruction, corruption, and subversion. In the first case the spirit of optimism prevails; in the second, that of indignation. As no one can escape from history, and as the present cannot be held of secondary importance, these stages of acceleration and retardation ill conceal the final victory of national aspirations. Following their line of evolution, they will eventually break the chains of reaction which bar their way and put an end to the policy of advancing only by short, deliberate steps.

The policy of retreat initiated by the coup d'état of April, 1964, $\dagger$ which interrupted democratic legality and the great political and civic debate on the subject of national reforms, was not an unforeseen eventu-

\footnotetext{
* The revolution of 1930 brought Getúlio Vargas to power.

$\dagger$ A military coup d'état overthrew President João Goulart and put the military in control of Brazil's destiny on April 1, 1964.
} 
ality, as can be discerned from passages of this essay. The false road taken by the National Democratic Union and other parties of the right, the deformed view of the evils of corruption (present in Brazilian history, as in that of other countries, ever since colonial days), the struggle against Communism (the dangers of which were exaggerated with a view to silencing inconformity and crushing less radical aspirations), the blockade raised against popular and labor-union leadership (despite the fact that it is demagogic and incompetent), the trust in popular respect for authority-all breed today as in the past the tendencies to coups d'état and conspiracies, which unfortunately characterize the political history of the country to a greater extent than is supposed.

As can be seen from this essay, if revolutions are not characteristic of Brazilian history, as is supposed by some American and European scholars who are wont to present a false view of the Brazilians, this does not mean that the nation's evolution was always a peaceful one. More characteristic of Brazil than revolution, whether bloody or peaceful, is conspiracy. One year after gaining its independence Brazil suffered its first coup d'état with the dissolution of the constitutional assembly on November 12, 1823.*

"Today rascals are having their day," José Bonifácio said to General José Manuel de Morais, the officer sent to arrest him. And from that time on, such days have succeeded one another with so great frequency in Brazilian history that the French minister to Brazil, Count Alexis de Saint-Priest, observed that, since no one was capable of governing, everyone engaged in intrigue, and the relation of the government to the opposition was not one of combat but of conspiracy.

He wrote in 1831, on the eve of another coup, of another conspiracy, the head of which, a confirmed conspirator, was to become regent of the Empire. The well-known reports of the French and Austrian ministers at the court show how the Lima e Silva family conspired under the leadership of Francisco the regent, $\dagger$ the father of Luís, the future Duke of Caxias.

The Swedish minister, M. de Ankarloo, whose diplomatic reports remain unpublished in the Royal Swedish Archives, declared flatly that

\footnotetext{
* Emperor Pedro I dissolved that assembly because of its vehement criticism of the Portuguese (Pedro had been born in Portugal) and because it sought to limit his powers, privileges, and prerogatives. Pedro then, in 1824, promulgated his own constitution, which lasted until the overthrow of the monarchy in 1889.

† When Pedro I abdicated in 1831 his son, Pedro II, was too young to exercise authority. Regents ruled in the name of the young emperor until 1840. Francisco de Lima e Silva was one of the early regents.
} 
the general "was viewed as the demagog in chief, for which reason doubtless he was made regent." Thus are confirmed previously known reports, including that of John Armitage, concerning the discontent, the intrigues, and the conspiracies of the Lima e Silvas. Already at that early date the sole exception was the future Duke of Caxias, the only member of the family who loyally proposed legal means of reacting to Dom Pedro I, as Capistrano de Abreu, Monsignor Pinto de Campos, and Alberto Rangel have reported.

From that time on, conspirators sought support from the army, and conspiracy à la Lima $\mathrm{e}$ Silva flourished therein. The conspirators profited while feigning to sacrifice themselves: "It was not to see Brazil ruined," said Francisco de Lima e Silva on the occasion of another little conspiracy aimed at preventing Araújo Lima, the future Marquis of Olinda, from taking office as sole regent, "that I and my family sacrificed ourselves on the seventh of April."

Lack of military discipline was so general and the conspiratory mentality so dominant that it was necessary to dissolve the army, reducing it to a merely symbolic fraction, and to create the National Guard, trained and directed by Major Luís Alves de Lima e Silva, the future Duke of Caxias, who found himself obliged to deny his father, the regent Francisco, and to devote all his efforts and all his force of discipline to the ends of peace in order that throughout the later history of the Empire the army might serve the constitution and legality alone.

From that time on, these two tendencies have alternated in Brazilian history. Predominance of one or the other among those in posts of command has determined in the constantly recurring crises the position of the army and, in consequence, whether constitutional order was to be maintained or to suffer chaotic interruption.

The crises of the Regency period, like those of the early days of the Republic, closely resemble the crises of the present day, both formally and structurally, though there has been an increase in the number of participating elements and in the degree of intensity. For some time the country has been subject to the army's varying inclination to support legality or intervention. This disturbs the nation's rhythm of growth and renders its path difficult; it represents tutelage over the people, who now number more than $85,000,000$. These citizens have the right to make decisions at the ballot box independent of the opinion of a few generals, who must answer to history for discrediting the nation, for interrupting the course of democracy, and for provoking the economic costs and damages of their interventions. 
The return to democratic legality, with the calling of elections, has at this moment become the most legitimate of national aspirations. The heirs of Caxias should ensure that it is achieved, guaranteeing to the people their rights and imposing on conspirators the triumph of discipline.*

\section{José HoNóRIo RoDRIGUES}

* The Duke of Caxias was a faithful servant of Emperor Pedro II, and, thanks to his powerful position in the army, he guaranteed the subservience of the military to the civilian government of the second emperor, 1840-1889. Subsequent leaders of Brazil's military have been less scrupulous in keeping the military outside politics. 